\title{
YORKSHIRE FOG (HOLCUS LANATUS). ITS POTENTIAL AS A PASTURE SPECIES
}

\author{
W. A. Jacgues \\ Palmerston North
}

YorkshiRe fog probably has its origin in the Iberian Peninsula (Vinal and Hein, 1937) but, as a result of continued colonizatioa since the end of the ice age, is now found throughout Europe from the limits of northern Scandinavia and Iceland to the Caucasus Mountains and North West Africa (Beddows, 1961; Hulten, 1950; Bocher and Larsen, 1958). Under the influence of human pastoral activities, the species has spread to all of the more recently developed farming areas in the temperate regions of the Americas, South Africa and Australasia.

Yorkshire fog was introduced into New Zealand either as a seed impurity or, more objectively, for use as a hay grass by settlers as recently as the 1860s. Owing to its aggressiveness and capacity for seed production, it has spread throughout the mainland and even to the more remote Chatham and Auckland Islands (Cheeseman, 1923; Stapledon, 1928). Under the equable climatic conditions in this country, its colonization limits probably exceed those observed in the British Isles, where the species is established in every district over a wide altitude range (Beddows, 1961).

The pasture surveys of the North and South Islands (Hilgendorf, 1935; Madden, 1940) record the association of Yorkshire fog with many major grassland communities, and McMeekan (1960) records it as contributing in no small way to the total production of many lowland dairy pastures, particularly in the Waikato.

Its climatic tolerance is characteristic of the important western European grasses and a high rate of growth is maintained at all temperatures from 12.8 to 29.4" C (Mitchell, 1956; Mitchell and Lucanus, 1960). In controlled environment studies at Grasslands Division, the growth of seedling plants showed general similarity to that of perennial and short-rotation ryegrass, cocksfoot and browntop. Its temperature tolerance occupies an intermediate position between perennial ryegrass and cocksfoot. Close study of the seasonal growth rhythms in a wide range of species (Lynch, 1949; Suckling, 1960) does in fact show a remarkable constancy of production in this reputedly undesirable species. 


\section{EDAPHIC TOLERANCE}

Concerning its value in marginal areas, one of its most important features is its almost complete absence of edaphic specialization (Levy, 1955; Beddows, 1961). Yorkshire fog is capable of growing on a wide range of soil types. Although the optimum soil reaction is considered to be within $\mathrm{pH} 5.0$ to 7.5 (Spurway, 1941; Davies, 1944), this grass is a notable colonist on areas of much higher aoidity. Yorkshire fog grows on areas representing extremes in soil moisture content but there is little apparent effeot on grass growth (Levy, 1955).

Studies by Mouat and Walker (1959), and Jackman (1960) of the cation-exchange capacity of the root systems of various grass and clover species tend to suggest that Yorkshire fog has a high competitive ability for phosphate, nitrogen and potash where their deficiency is a major faotor limiting the growth of plants of higher ecological succession.

\section{BIOTIC TOLERANCE}

Although Yorkshire fog will persist under a wide range of management regimes, its general growth habit and system of vegetative reproduction are mast suited to a lenient system of defoliation and the maintenance of a fair degree of herbage cover.

Controlled environment studies (Mitchell, 1956) support the existing evidence that this grass is intermediate between perennial ryegrass and cocksfoot in its tolerance to defoliation. In the sward, the growth of the fog plant is centred on leaf expansion on a moderate number of large tillers, whereas in ryegrass and browntop it is on a large number of small tillers. Thus at a constant temperature of 18 " C equivalent growth is obtained from 50 tillers of Yorkshire fog or cocksfoot, 80 tillers of short-rotation ryegrass, 100 tillers of perennial ryegrass, or 350 tillers of browntop.

In view of the wide variation in growth forms which occurs in this species and the varying reaction of each form to grazing, it is unwise to make a blanket statement regarding the biotic effect without stipulating the growth form. It would appear that some forms caa tolerate trampling and close defoliation while others are 'adversely affected by it, but no trials to determine the growth form responses have been undertaken. It is reasonable to suppose that the more valuable agronomic forms will be found among the more erect types. 


\section{PALATABILITY}

Yorkshire fog has a reputation as being an unpalatable species to farm stock. This is undoubtedly true where poor pasture management is practised and applies equally to perennial ryegrass.

In view of the wide variation in growth forms which occurs assessment is invalid, for without doubt some forms are seen to be attractive to stack and are kept well grazed. Others would appear to be unattractive and are allowed to become rank. Studies on the grazing preferences of sheep on spaced plant material show that preferences and growth form are closely linked (Munro, 1961).

The possibility of improving relative palatability by selection and breeding within the species is quite high. Studies of the grazing preference of sheep on spaced plant material at Massey have revealed a relationship between low palatability and the following features:

(1) Prolific flower-head production.

(2) Severe infection by Crown rust (Puccinia coronata).

(3) Extreme prostrate habit of growth.

(4) Pubescence.

The digestibility of the herbage is equivalent to that of many of the so-called "better" grasses (W. F. Raymond, 1958, pers. comm.) . Fagan and Milton (193 1) found that growth' stage was more important than species in determining nutritive value. The physiological processes associated with floral emergence result in both a decline of crude protein and a rise in crude fibre content of the dry matter. The main problem with this grass lies not in its feed value but rather in its palatability and tolerance of grazing. No crude protein determinations were made during the trial, but studies made at Te Awa (Suckling, 1960) demonstrate the improbability of any deficiency in Yorkshire fog in this respect. Over a two-year period, the average crude' protein content of this species was $19.5 \%$ compared with 17.6 and $18.8 \%$ for short-rotation and perennial ryegrass, respectively.

\section{UTILIZATION OF ECOTYPIC VARIATION IN NEW. ZEALAND} POPULATIONS

Poehlman (1959) wrote, "Natural selection is so simple in its application and yet so forceful in its results that no serious 
consideration should be given to methods for improvement of a particular forage species that does not utilize the benefits already achieved in nature." The selection of suitable ecatypes naturally follows.

Despite the relatively recent development of New Z\&and's grassland, considerable ecotypic development has been shown to occur in the major out-breeding species - e.g., perennial ryegrass (Levy and Davies, 1930), cocksfoot (Calder, 1933) and timothy (Gorman, 1950). Yorkshire fog shows comparable development. As in Europe, she variation pattern strongly reflects the recurrence of certain climatic, biotic and edaphic sequences, each characteristic being closely associated with the active growing period, the temperature regime, the incidence of seasonal moisture stress, and the influence of the grazing animal. In New Zealand natural selection has taken place to such an extent that variability is seen to be following that found in the centre of origin (Europe). New Zealand has, in fact, become a new centre of diversity of the species (Munro, 1961; Jacques, 1962).

In 1954, 151 seed samples were obtained from diverse areas of the North and South Islands but none was obtained from Westland and only two from Northland. In view of subsequent findings this was an unfortunate omission, for Northland has shown itself to be the region where ecoclinal trends give growth forms considered to be moist suitable for grazing purposes.

These samples were grown out as single plants and observations on growth form (erect through to extreme prostrate growth) leaf shape (broad flat through to narrow rolled), leaf colour (from very light to very dark green), earliness end lateness of flowering, recovery growth, and degree of rust infection were made by Basnyat (1957).

Plants were selected on the basis of observed merit points in single plants. Polycross material was obtained using 32 of the mast promising parents and in 1959-60 three site's were selected for the progeny testing, of the polycross material. Two areas were established by the New Zealand Department of Agriculture on newly developed peat at Lake Cameron and at Moanatautau, near Rukuhia Soil Research Station at Hamilton. Results from these areas were used to substantiate the findings made at the main centre at Massey College (Van der Elst and Corby, 1960). Ten lines with a high potential as parent plants were identified. In the formation of synthetic varieties it is essential to maintain a uniformity of heading time within the parental material, thus 
preventing the possibility of considerable genetic drift during seed multiplication. Most of these ten lines were late flowering but there were four which showed a tendency towards earlier flowering. When the first synthetic was compounded in 1960, eight lines were incorporated. While this selection contains a high level of adaptability, the variation in heading performance and growth form may prove to be a hazard in seed multiplicatioa .

It is not intended that this synthetic should represent the ultimate that it is possible to attain. Even so, it was considered to be so much better than commercial seed that it was registered under the name "Basyn". I am fully convinced that Auckland province and especially North Auckland holds the best potential breeding material to be found in New Zealand. This is well shown by Munro ( 1961 ) who postulates that ecoclinal variation from south to north of New Zealand shows an increasing persistency and vigour and resistance to rust with an increasing proportion of erect and first year flowering plants. These plants had developed in a region with a 12-month active growing season where dormancy as is found in the country lying below the $7.2^{\circ} \mathrm{C}$ July isotherm (i.e., the greater part of the South Island) does not feature.

\section{INTERSPECJES COMPETITION}

In 1905, Clements stated: "Competition is purely a physical process. With few exceptions an actual struggle between compting plants never occurs. Competition arises from the reaction of one plant upon the physical factors about it and the effect of these modified factors upon its competitors. In the exact sense. two' plants, no matter how close, do not compete with each other as long as the water content, the nutrient material, the light and heat are in "excess of the needs of both. When the immediate supply of a such necessary factor falls below the combined demand of the plants competition begins".

This concept is still valid but with a single modification that certain plants gain a competitive advantage 'through toxic exudates.

In recent years light has come to be regarded as one of the major limiting factors in crop production, especially in pasture communities, and study of it has been delayed through difficulty in measuring and defining the light climate and in reproducing normal daylight by artificial means under controlled conditions. 
Doaald (1951), referring to the influence of plant density on pasture production, has stated that "light is the factor which determines the ultimate yield of a community of plants of a particular species", and that if water and nutrieats are not restrictive then light and light only has become the limiting factor governing growth per unit area. In other words, "the ultimate capacity of a species to produce dry matter depends on the degree to which a community of such plants can exploit the light falling on it."

Riveros (1963) undertook a trial to elucidate competitive factors between Yorkshire fog (synthetic), certified perennial ryegrass and certified white clover. The layout was based on the technique described by Gardner (1960) where it was possible to keep the plants individualized throughout the experiment and to keep records of dominance, suppression and mortality of the species studied. This was achieved by laying a wire mesh with 3 -inch squares covering the experimental area and planting one plant in each. The most suitable design was found to be a $2 \times 5$ factorial (comprising two heights of cutting - short, 3 in. to 1 in.; long, 5 in. to 2 in.) and five combinations of species in three replications.

Dry matter was determined, leaf areas and widths were measured, and point analyses made to determine the distribution of leaves in the vertical layers (Levy and Madden, 1933). Light measurements were made at $1 \mathrm{in}$. from the ground within the vegetation and expressed as a percentage of the light intensity on a horizontall plane outside the pasture. Temperatures at ground level were recorded, tiller counts made, and any diseases (He!minthosporium in ryegrass and Pseudopiziza in white clover) kept in check with sprays.

The technique used in this trial had the advantage that individual plants of the grass species could be examined throughout the experimental period.

A summary of the findings is as follows:

(1) Dry matter yields were always significantly higher in those treatments that included Yorkshire fog and increased throughout the experimental period (12 moaths) .

(2) Perennial ryegrass when grown in combination with Yorkshire fog gave progressively lower yields because of suppression.

(3) Yorkshire fog grown with white clover suppressed it at both levels of cutting. 
(4) Perennial ryegrass with white clover at both cutting levels allowed for high yield in the clover.

(5) Yorkshire fog under conditions of no treading spread by runners which formed a thick mat that interferred with the normal growth of the companion species thus giving it a competitive advantage.

(6) There was greater light interception by Yorkshire fog than by the other species. This was apparent early in the trial and increased to the end of the trial.

(7) The wider leaves of Yorkshire fog enabled it to utilize incoming light more effectively. Leaf area indices were significantly higher in those treatments where Yorkshire fog was present.

(8) Yorkshire fog at the end of the trial had over two-thirds more tillers than perennial ryegrass grown in the same plots.

(9) It was concluded that interception of incoming light to both perennial ryegrass and white clover was' the determining factor that caused suppression by Yorkshire fog, since nutrients and moisture were non-limiting.

While in the above trial Yorkshire fog showed a high degree of aggressiveness, such an effect could well be modified under grazing.

There is a low proportion of both strengthening tissue and collateral vascular bundles in the leaves, and theoretically the feeding value should be high, but comparative chemical analyses give no clue to any differences in feeding value between Yorkshire fog and perennial ryegrass. This lack of strengthening tissue in the leaves is shown in Table 1. The breaking strain index $=$

\section{Load at moment of failure $(\mathrm{g})$}

Width near leaf base $(\mathrm{mm})$

and was measured at the Grasslands Division.

TABLE 1: BREAKING STRAIN ON LEAVES OF FOUR GRASSES

\begin{tabular}{|c|c|c|c|c|c|}
\hline Species & & & Oldest Leaf & Middle Leaf & Younger Leaf \\
\hline Perennial ryegrass & 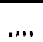 & & 36.4 & 43.9 & 38.5 \\
\hline Lung rotation & $\ldots$ & .". & 29.8 & 31.8 & 26.6 \\
\hline Short rotation & & $\ldots$ & 25.3 & 28.3 & 17.7 \\
\hline Yorkshire fog & ..י & $\ldots$ & 8.7 & 7.2 & 5.5 \\
\hline
\end{tabular}


The heavy damage possible to the leaf with stocking at high rates could affect Yorkshire fog more than the ryegrasses. There is no doubt that the abundance of Yorkshire fog can be controlled by grazing, by both reducing leaf area and at the same time causing mechanical damage to the leaf.

In grazing trials at Massey with sheep (1961-2) total dry matter production $(\mathrm{kg} / \mathrm{ha})$ was as follows:

\begin{tabular}{lccccr}
\hline & & Total Yield & G rass & Clover & W eeds \\
\hline Perennial ryegrass & $\ldots$ & 10430 & 8630 & 1180 & 620 \\
Long rotation & $\ldots$ & 11320 & 9980 & 730 & 620 \\
$\begin{array}{l}\text { Short rotation } \\
\text { Yorkshire fog }\end{array} \quad \ldots$ & 10760 & 8690 & 1420 & 650 \\
$\quad$ (synthetic strain) & 11550 & 9190 & 1680 & 670 \\
\hline
\end{tabular}

With all the above evidence of the potentiality of Yorkshire fog as a grazing plant, efforts should be made to improve the parental material by ecotypic selection from suitable areas in the north of the North Island, where the most promising material is to be found. This may ensure a better image for this plant and a widening of its application to grassland farming in New Zealand and possible export of seed to areas where it could be profitably employed.

\section{REFERENCES}

Basnyat, M. B., 1957: Thesis, Massey Agricultural College.

Beddows, A. R., 1961: J. Ecol. 49: 421.

Bocher, T. W.; Larsen, K., 1958: B of. Notiser, 111: 289.

Calder, J. W., 1933: Bull. imp. Bur. PI. G enet. Herb. 1136.

Cheeseman, T. F., 1923: Manual of the New Zealand Flora, 2nd ed., Government Printer, Wellington.

Clements, F. E., 1905: R esearch M ethods in Ecology. Univ. Pub. Co., Linc., Nebraska.

Davies, E. B., 1944: N.Z. JI Agric., 69: 529.

Donald, C. M., 1951: Aust. J. Agric. Res: 2: 355.

Fagan, T. W.; Milton. W. E. J., 1931: Ẅelsh J. Agric., 7: 246.

Gardner, A. L., 1960: Proc. 8th int. Grassld Congr.: 322.

Gorman, L. W., 1950: N.Z. Il Sci. Tech., 32A: 1.

Hilgendorf, F. W., 1935: N.Z. Dept. sci. industr. Res., 47: 24 pp.

Hulten, E., 1950: Atlas of Distribution of Vascular Plants in N.W. Europe, Stockholm.

Jackman, R. H., 1960: Sheepfmg A.: 75.

Jacques, W., 1962: Proc. N.Z. G rassId Ass., 24: 139.

Levy, E. B., 1955: Grasslands of N ew Zealand, 2nd ed. Government Printer, Wellington. $322 \mathrm{pp}$.

Levy, E. B.; Davies, W., 1930: N.Z. Jl Agric., 40: 363.

Levy, E. B.; Madden, E. A., 1933: N.Z. Jl Agric., 46: 261.

Lynch, P. B., 1949: Proc. N.Z. Grassld Ass., 11:151. 
McMeekan, C. P., 1960: Grass to Milk. N.Z. Dairy Exporter, Wellington. $193 \mathrm{pp}$.

Madden, E. A., 1940: N.Z. Dept sci. industr. Res. Bull., 47: 24 pp.

Mitchell, I<. J., 1956: N.Z. /l Sci. Tech., 38A: 208.

Mitchell, K. J.; Lucanus, R., 1960: N.Z. Il agric. Res., 3: 647.

Mouat, M. C.; Walker, P. C., 1959: PI \& Soil, 11: 41.

Munro, M. M., 1961: Thesis, Massey Agricultural College.

Poehlman, J. M., 1959: Breeding Field Crops. Holt, New York, 422 pp.

Riveros, F., 1963: Thesis, Massey Agricultural College.

Spurway, C. H., 1941: Spec. Bull. Mich. agric. Exp. Stn 306:

Stapledon, R. G., 1928: /. Ecol., 76: 71.

Suckling, F. E. T., 1960: N.Z. Il agric. Res., 3: 579.

Van der Elst, F. C. C. H.; Corby; J. P., 1960: Rukuhia Soil Research Stn (unpublished data).

Vinal, H. N.; Hein, M. A., 1937: U.S. Dept Agric. Yearbook: 1032. 